Vol. 2 No. 3, Juli 2018;

\title{
Peningkatan Hasil Belajar IPS Melalui Pemberian Tugas Membuat Kesimpulan dengan Kartu Pada Siswa SMP
}

\author{
Ta'awan ${ }^{(1)}$ \\ 1 SMPN 1 BLITAR \\ Email: ${ }^{1}$ d_shin13@yahoo.com, \\ DOI: https://doi.org/10.28926/riset_konseptual.v2i3.61
}

\begin{abstract}
ABSTRAK
Penelitian Tindakan Kelas ini bertujuan untuk mengatasi kesulitan-kesulitan siswa dalam menyelesaikan soal-soal IPS yang berkaitan dengan Sub Tema Tumbuh dan berkembannya semangat kebangsaan pada pembelajaran IPS semester 2 kelas II-A. Penelitian ini juga bertujuan untuk mengetahui sejauh mana dapat meningkatkan hasil belajar siswa. Subyek penelitiannya adalah siswa kelas II-A SMP Negeri 1 Kota Blitar, dengan jumlah laki-laki 14 orang dan siswa perempuan sebanyak 19 orang. Penelitian ini berlangsung selama 3 siklus dengan jumlah tatap muka sebanyak 6 kali. Data setiap siklus diperoleh melalui kuesioner motivasi, respon siswa terhadap materi kegiatan belajar mengajar, nilai hasil Pra Siklus serta catatan hasil pengamatan guru mitra. Dari kegiatan menunjukkan bahwa dengan pemberian tugas membuat kesimpulan dengan kartu tingkat keaktifan siswa dalam belajar kelompok pada siklus 1 siswa yang aktif membuat kesimpulan dengan kartu sebesar $62 \%$, siswa yang aktif mencatat pelajaran $69,1 \%$ dan siswa yang memperoleh nilai kategori baik dan amat baik sebesar $80,96 \%$; Pada siklus 2 siswa yang aktif membuat kesimpulan dengan kartu sebesar $69,05 \%$, siswa yang aktif mencatat pelajaran $76,2 \%$ dan siswa yang memperoleh nilai kategori baik dan amat baik sebesar $85,72 \%$; Pada siklus 3 siswa yang aktif membuat bimpulan dengan kartu sebesar $85,70 \%$, siswa yang aktif mencatat pelajaran $90,47 \%$ dan siswa yang memperoleh nilai kategori baik dan amat baik sebesar $92,85 \%$.
\end{abstract}

Kata kunci: hasil belajar, ips, tugas, membuat kesimpulan

\section{PENDAHULUAN}

Kenyataan di lapangan bahwa siswa mengalami banyak kesulitan dalam menyelesaikan soal-soal IPS. Jika siswa menerima soal-soal latihan, rata-rata siswa tidak bersemangat dan tidak mau berusaha keras untuk memahami apalagi untuk menyelesaikannya. Padahal kita tahu memahami atau menyimak isi soal merupakan langkah awal menuju penyelesaian. Akibatnya apabila soal-soal Ulangan Harian ada yang berbentuk uraian, maka sebagian besar siswa tidak dapat menyelesaikannya, sehingga nilai ulangan yang diperoleh rata-rata relatif rendah atau di bawah kreteria ketuntasan minimal.

Berdasarkan uraian di atas, peneliti berusaha mencari solusi dengan cara pemberian tugas kepada siswa melalui pembuatan kesimpulan yang dituliskan pada kartu pada setiap 15 menit di akhir pertemuan. Solusi ini diharapkan dapat meningkatkan motivasi belajar dan prestasi belajar. Pada prinsipnya membuat kesimpulan dengan kartu adalah membuat rangkuman materi atau kesimpulan yang mudah dipahami, mudah dibawa, menarik karena diberi warna yang bervariasi.

Penerapan teknik membuat kesimpulan dengan kartu merupakan langkah maju yang diharapkan dapat meningkatkan motivasi belajar siswa dalam memahami konsep-konsep IPS yang berkaitan dengan sistem perekonomian Indonesia. Agar teknik tersebut berjalan sesuai dengan harapan, maka guru perlu membimbing siswa dalam membuat kesimpulan dengan kartu, adapun caranya adalah memberikan selembar kartu pada siswa di setiap 15 menit diakhir pertemuan.

Menurut ( PPGM, 1999:5-6 ) dijelaskan bahwa : (a) adanya korelasi positif antara Membuat Kesimpulan Dengan Kartu dengan prestasi belajar siswa, khususnya mata IPS. Untuk mengembangkan kemampuan siswa dalam Membuat Kesimpulan Dengan Kartu, guru perlu memberikan contoh dengan cara sebagai berikut: (1) 
Vol. 2 No. 3, Juli 2018;

Membuat contoh Kesimpulan Dengan Kartu dari yang umum ke hal-hal yang khusus atau dari hal-hal yang bersifat deduktif ke hal-hal yang besifat induktif. (2) Guru memberi contoh model Kesimpulan Dengan Kartu. (3) Setelah diberi beberapa contoh, selanjutnya siswa diberi tugas Membuat Kesimpulan Dengan Kartu sesuai dengan pokok bahasan yang diberikan.

Dalam memberikan tugas, siswa bekerja secara individu. Hal ini dimaksudkan agar guru mudah memantau aktifitas siswa selama pelaksanaan pemberian tugas berlangsung, dan memudahkan guru dalam pemeriksaan hasil kegiatan.

Untuk dapat meningkatkan kemampuan siswa dalam menyerap materi Tumbuh dan Berkembanya semangat Kebangsaan, guru perlu memberikan tugas secara individual. Pemberian Tugas dikembangkan dan dimodifikasi dimana siswa bukan hanya menyelesaikan soal, tetapi setiap individu akan mengerjakan juga soalsoal yang telah dibuat oleh guru. Selain itu agar suasana pemberian tugas menarik dan menyenangkan, maka individu yang mampu menyelesaikan soal lebih dahulu dari individu lain, maka guru akan memberikan bonus.

Kerberhasilan pelaksanaan tindakan ini dapat dilihat dari kemampuan siswa dalam Membuat Kesimpulan Dengan Kartu, serta dari kemampuan siswa dalam mengerjakan soal-soal latihan. Apabila kemampuan siswa dalam Membuat Kesimpulan Dengan Kartu berjalan secara benar berarti kemampuan siswa dalam menerapkan pembuatan Kesimpulan Dengan Kartu juga meningkat.

Setiap kegiatan belajar yang sedang berlangsung hendaknya melibatkan seluruh siswa, sehingga siswa tersebut dapat berpartisipasi aktif dalam topik yang sedang dibicarakan. Siswa akan berhasil dengan baik bila dalam pembelajaran berpartisipasi secara aktif (Sawunggaling, 1984 hal 159).

Tugas membuat kesimpulan yang dimaksud disini adalah tugas membuat kalimat-kalimat inti yang tersusun dalam bentuk sederhana, agar mudah difahami. Pemberian tugas membuat kesimpulan daam proses belajar juga dapat membantu siswa menghubungkan informasi yang diterima dan mendorong semangat belajar, seperti diungkapkan oleh Mursiah (1987, hal. 38) Dengan membuat kesimpulan, siswa akan terlatih untuk berpikir, memahami serta mengungkapkan dengan kata-kata sendiri tentang mata pelajaran yang dipelajari dan dapat pula mendorong semangat belajar.

Pada kegiatan ini, tugas membuat kesimpulan dilakukan pada selembar kartu yang berukuran $15 \mathrm{~cm} \times 10 \mathrm{~cm}$. Keuntungan penggunaan kartu diungkapan oleh Lobby Lukman (1994 : 105) untuk membantu dalam mengingat satu pokok pikiran.

Adapun kelebihan dari sistem kartu ini adalah memudahkan siswa menghafal. Hal ini sesuai dengan apa yang dikemukakan oleh The Liang Gie (1985: 119) : Faedah sistem kartu ini adalah jika kelak mahasiswa ingin menghafal misalnya mengenai pohon-pohon apa saja yang hanya tumbuh di suatu macam tanah tertentu, dia hanya tinggal mengambil kartu-kartu yang bersangkutan untuk dikumpulkan menjadi satu. Kalau perlu mahasiswa dapat membandingkan kegunaan pohon yang satu dengan pohon yang lain. la dapat meletakkan dua kartu itu di depannya. Dengan demikian ia dapat mempelajari dengan lebih praktis.

Teori di atas sangat mendukung pemberian tugas membuat kesimpulan, sebagai salah satu upaya meningkatkan motivasi belajar siswa.

\section{METODE}

Penelitian direncanakan dengan mengimplementasikan penelitian tindakan kelas yang meliputi komponen - komponen : 1) Perencanaan / Planning, 2) Tindakan / Acting, 3) Observasi / Obserfing, 4) Refleksi / Reflekting.

Penelitian berlangsung selama 2 bulan dari akhir Bulan Maret 2018 sampai dengan akhir Bulan Mei 2018 yang terbagi dalam 3 Siklus, masing-masing siklus dengan alokasi waktu 3 minggu ( 3 X 90 menit ), setiap akhir siklus diakhiri dengan refleksi dan replanning untuk melanjutkan pada Siklus 2 dan 3. 


\begin{tabular}{|l|l|c|c|}
\hline \hline 1 & Aktif & 22 orang & $69,05 \%$ \\
\hline 2 & Cukup Aktif & 9 orang & $23,80 \%$ \\
\hline 3 & Tidak Aktif & 2 orang & $7,15 \%$ \\
\hline \hline \multicolumn{2}{|c|}{ Jumlah } & 33 orang & $\mathbf{1 0 0 \%}$ \\
\hline
\end{tabular}

Ditinjau dari perolehan nilai hasil tes dapat dilihat pada tabel 3.

Tabel 3 Distribusi Frekuensi Data Perolehan Nilai Siswa Pada Siklus I

\begin{tabular}{|c|c|c|c|c|}
\hline \multirow{2}{*}{$\begin{array}{c}\text { Kelompok } \\
\text { Nilai }\end{array}$} & \multirow{2}{*}{ Interval Nilai } & \multicolumn{2}{|c|}{ Siklus 1 } & \multirow{2}{*}{ Kualitas Nilai } \\
\cline { 3 - 4 } & & Frekuensi & Persentasi & \\
\hline \hline 1 & $0-55$ & - orang & $0 \%$ & Kurang \\
\hline 2 & $56-69$ & 7 orang & $19,04 \%$ & Cukup \\
\hline 3 & $70-79$ & 22 orang & $69,04 \%$ & Baik \\
\hline 4 & $80-100$ & 4 orang & $11,92 \%$ & Amat Baik \\
\hline
\end{tabular}

Berdasarkan hasil pelaksanaan dan pengamatan pada siklus pertama ditemukan hal-hal sebagai berikut: (1) Dilihat dari keaktifan dalam belajar siswa yang tidak aktif 3 orang $(7,15 \%)$ dari 33 siswa. (2) Dilihat dari keaktifan mencatat materi yang diberikan, siswa yang tidak aktif mencatat ada 3 orang $(7,15 \%)$ dari 33 siswa. (3) Dilihat dari perolehan nilai tes siswa yang memperoleh nilai baik hanya 22 orang $(69,4 \%)$, tetapi yang memperoleh nilai kurang jumlahnya 0 orang $(0 \%)$ dar i33 siswa.

\section{Siklus II}

Berdasarkan dari hasil catatan di lapangan, pada saat berlangsungnya proses belajar mengajar ada seorang siswa melempar kartu ke arah temannya berulangulang. Guru menegur dan menyuruh aktif berinteraksi dengan kelompoknya masingmasing. 2 orang siswa lainnya berbincang-bincang tentang sesuatu yang tidak terkait dengan materi pembelajaran. Pada tiap kelompok yang paling antusias membahas tugas yang diberikan oleh guru ada 2 atau 3 orang, sementara yang lain cukup aktif.

Adapun pengamatan diluar proses belajar kelompok yaitu guru memeriksa buku catatan setiap siswa setelah materi diberikan. Ternyata masih ada siswa yang tidak mencatat dengan alasan tidak membawa buku. Ditinjau dari keaktifan siswa dalam belajar kelompok terdapat data-data sebagai berikut, seperti tersaji pada tabel 4 , 5 dan 6.

\section{Tabel 4 Keaktifan Siswa Dalam Membuat Kesimpulan Dengan Kartu Pada Siklus} II

\begin{tabular}{|c|l|c|c|}
\hline \multirow{2}{*}{ No } & \multirow{2}{*}{ Keaktifan Siswa } & \multicolumn{2}{|c|}{ Siklus 2 } \\
\cline { 3 - 4 } & & Frekuensi & Persentasi \\
\hline \hline 1 & Aktif & 22 orang & $69,05 \%$ \\
\hline 2 & Cukup Aktif & 8 orang & $23,80 \%$ \\
\hline 3 & Tidak Aktif & 3 orang & $7,15 \%$ \\
\hline \hline \multicolumn{2}{|c|}{ Jumlah } & 33 orang & $\mathbf{1 0 0} \%$ \\
\hline
\end{tabular}

Ditinjau dari keaktifan siswa dalam mencatat materi yang diberikan melalui pengamatan lembar catatan dapat dilihat pada tabel 5 .

Tabel 5 Keaktifan Siswa Dalam Mencatat Materi Pembelajaran Pada Siklus II

\begin{tabular}{|c|l|c|c|}
\hline \multirow{2}{*}{ No } & \multirow{2}{*}{ Keaktifan Siswa } & \multicolumn{2}{|c|}{ Siklus 2 } \\
\cline { 3 - 4 } & & Frekuensi & Persentasi \\
\hline \hline 1 & Aktif & 26 orang & $76,2 \%$ \\
\hline
\end{tabular}




\begin{tabular}{|l|l|c|c|}
\hline 2 & Cukup Aktif & 5 orang & $19,9 \%$ \\
\hline 3 & Tidak Aktif & 2 orang & $3,9 \%$ \\
\hline \hline \multicolumn{2}{|c|}{ Jumlah } & $\mathbf{3 3}$ orang & $\mathbf{1 0 0 \%}$ \\
\hline
\end{tabular}

Ditinjau dari perolehan nilai hasil tes dapat dilihat pada tabel 6.

Tabel 6 Distribusi Frekuensi Data Perolehan Nilai Siswa Pada Siklus II

\begin{tabular}{|c|c|c|c|c|}
\hline \multirow{2}{*}{$\begin{array}{c}\text { Kelompok } \\
\text { Nilai }\end{array}$} & \multirow{2}{*}{ Interval Nilai } & \multicolumn{2}{|c|}{ Siklus 2 } & \multirow{2}{*}{ Kualitas Nilai } \\
\cline { 3 - 4 } & & Frekuensi & Persentasi & \\
\hline \hline 1 & $0-55$ & - orang & $0 \%$ & Kurang \\
\hline 2 & $56-69$ & 6 orang & $14,28 \%$ & Cukup \\
\hline 3 & $70-79$ & 24 orang & $78,57 \%$ & Baik \\
\hline 4 & $80-100$ & 3 orang & $7,15 \%$ & Amat Baik \\
\hline
\end{tabular}

Berdasarkan hasil pelaksanaan dan pengamatan pada siklus kedua ada sedikit peningkatan jika dibandingkan dengan siklus 1 yaitu: (1) Dilihat dari keaktifan dalam belajar kelompok siswa yang tidak aktif 3 orang $(7,15 \%)$ dari 33 siswa. (2) Dilihat dari keaktifan mencatat materi yang diberikan, siswa yang tidak aktif mencatat ada 2 orang $(3,9 \%)$ dari 33 siswa. Dilihat dari perolehan nilai tes siswa yang memperoleh nilai baik hanya 33 orang $(78,57 \%)$, sedangkan yang memperoleh nilai amat baik berjumlah 3 orang $(7,15 \%)$, tetapi yang memperoleh nilai kurang jumlahnya 0 orang $(0 \%)$ dari 42 siswa.

\section{Siklus III}

Berdasarkan dari hasil catatan di lapangan, pada saat berlangsungnya proses belajar mengajar semua siswa sudah memahami proses pembelajaran dengan teknik membuat kesimpulan dengan kartu. Guru tinggal memebrikan penguatan dalam rangka menumbuhkan motivasi belajar. Adapun hasil pengamatan pada silus ketiga dapat dilihat pada tabel 7, 8 dan 9.

Tabel 7 Keaktifan Siswa Dalam Membuat Kesimpulan Dengan Kartu Pada Siklus III

\begin{tabular}{|c|l|c|c|}
\hline \multirow{2}{*}{ No Keaktifan Siswa } & \multicolumn{2}{c|}{ Siklus 2 } \\
\cline { 3 - 4 } & \multirow{2}{*}{ Koktif } & Frekuensi & Persentasi \\
\hline 1 & Ak orang & $85,70 \%$ \\
\hline 2 & Cukup Aktif & 5 orang & $11,90 \%$ \\
\hline 3 & Tidak Aktif & 1 orang & $2,40 \%$ \\
\hline \hline \multicolumn{2}{|c|}{ Jumlah } & 33 orang & $\mathbf{1 0 0 \%}$ \\
\hline
\end{tabular}

Ditinjau dari keaktifan siswa dalam mencatat materi yang diberikan melalui pengamatan lembar catatan dapat dilihat pada tabel 8.

Tabel 8 Keaktifan Siswa Dalam Mencatat Materi Pembelajaran Pada Siklus III

\begin{tabular}{|c|l|c|c|}
\hline \multirow{2}{*}{ No } & \multirow{2}{*}{ Keaktifan Siswa } & \multicolumn{2}{c|}{ Siklus 3 } \\
\cline { 3 - 4 } & & Frekuensi & Persentasi \\
\hline \hline 1 & Aktif & 29 orang & $90,47 \%$ \\
\hline 2 & Cukup Aktif & 4 orang & $9,53 \%$ \\
\hline 3 & Tidak Aktif & - orang & $0 \%$ \\
\hline \hline \multicolumn{2}{|c|}{ Jumlah } & 33 orang & $\mathbf{1 0 0 \%}$ \\
\hline
\end{tabular}


Vol. 2 No. 3, Juli 2018;

Ditinjau dari perolehan nilai hasil tes dapat dilihat pada tabel 9.

Tabel 9 Distribusi Frekuensi Data Perolehan Nilai Siswa Pada Siklus 3

\begin{tabular}{|c|c|c|c|c|}
\hline \multirow{2}{*}{$\begin{array}{c}\text { Kelompok } \\
\text { Nilai }\end{array}$} & \multirow{2}{*}{ Interval Nilai } & \multicolumn{2}{|c|}{ Siklus 3 } & \multirow{2}{*}{ Kualitas Nilai } \\
\cline { 3 - 4 } & $0-55$ & Frekuensi & Persentasi & \\
\hline \hline 1 & $56-69$ & orang & $0 \%$ & Kurang \\
\hline 2 & $70-79$ & 25 orang & $7,15 \%$ & Cukup \\
\hline 3 & $80-100$ & 5 orang & $11,90 \%$ & Baik \\
\hline 4 & \multicolumn{2}{|c}{} & Amat Baik \\
\hline
\end{tabular}

Berdasarkan hasil pelaksanaan dan pengamatan pada siklus kedua ada sedikit peningkatan jika dibandingkan dengan siklus 1 yaitu: (1) Dilihat dari keaktifan dalam belajar kelompok siswa yang tidak aktif 1 orang $(2,40 \%)$ dari 33 siswa. (2) Dilihat dari keaktifan mencatat materi yang diberikan, siswa yang tidak aktif mencatat ada - orang (0\%) dari 33 siswa. (3) Dilihat dari perolehan nilai tes siswa yang memperoleh nilai baik hanya 25 orang $(81 \%)$, sedangkan yang memperoleh nilai amat baik berjumlah 5 orang ( $12 \%)$, tetapi yang memperoleh nilai kurang jumlahnya 0 orang( $0 \%)$ dari 33 siswa.

\section{PEMBAHASAN}

Tugas membuat kesimpulan ini diberikan sebelum pelajaran berakhir, siswa menulis kesimpulan pada kartu. Setelah itu kartu dikumpulkan untuk diperiksa dan dinilai oleh guru, kemudian dikembalikan lagi kepada siswa untuk dimanfaatkan sebagai sumber belajar, selain catatan yang ada pada siswa.

Sebelumnya guru memberikan tes untuk mengetahui kemampuan awal siswa. Selanjutnya penulis melaksanakan kegiatan belajar mengajar seperti yang tertuang dalam rencana pelajaran. Pada akhir pelajaran penulis membagikan kartu kepada siswa untuk ditulisi dengan kesimpulan-kesimpulan yang penting dalam pelajaran hari itu.

\section{KESIMPULAN}

Dari kegiatan menunjukkan bahwa dengan pemberian tugas membuat kesimpulan dengan kartu tingkat keaktifan siswa dalam belajar kelompok pada siklus 1 siswa yang aktif membuat kesimpulan dengan kartu sebesar $62 \%$, siswa yang aktif mencatat pelajaran $69,1 \%$ dan siswa yang memperoleh nilai kategori baik dan amat baik sebesar 80,96\%; Pada siklus 2 siswa yang aktif membuat kesimpulan dengan kartu sebesar $69,05 \%$, siswa yang aktif mencatat pelajaran $76,2 \%$ dan siswa yang memperoleh nilai kategori baik dan amat baik sebesar $85,72 \%$; Pada siklus 3 siswa yang aktif membuat bimpulan dengan kartu sebesar $85,70 \%$, siswa yang aktif mencatat pelajaran $90,47 \%$ dan siswa yang memperoleh nilai kategori baik dan amat baik sebesar 92,85\%. Dengan demikian Model pembelajaran membuat kesimpulan dengan kartu dapat meningkatkan keaktifan siswa dalam proses pembelajaran yang pada akhirnya akan dapat meningkatkan prestasi belajar siswa.

\section{SARAN}

Dalam penerapan pembuatan kesimpulan dengan kartu, guru hendaknya lebih teliti dan mengadakan observasi secara cermat. Agar siswa dalam pembelajaran IPS lebih termotivasi dan aktif, sebaiknya guru IPS dapat menerapkan teknik pembuatan kesimpulan dengan kartu secara kelompok dengan pertimbangan dapat menumbuhkembangkan intelektual siswa yang kreatif, inovatif dan konstruktif.Untuk mengetahui keberhasilan mengajar dan belajar maka setiap akhir pembelajaran siswa perlu diberikan Evaluasi dalam bentuk pos test. 


\section{DAFTAR RUJUKAN}

A. Tabrani Rusyan. 1992. Pendekatan Dalam Belajar Mengajar, Remaja Rusda Karya, Ali, Mohammad. 1987. Kegiatan Kependidikan Prosedur dan Strategi. Bandung: Angkasa Bandung.

Amin. M. 1990. Pemetaan Konsep Suatu Teknik Untuk Meningkatkan Belajar Yang Bermakna, Jakarta: Mimbar Pendidikan.

Bulkani. 1992. Studi Tentang Belajar Kelompok Kaitannya Dengan Prestasi Belajar Siswa. Palangkaraya: UNPAR.

Gie, The Liang. 1982. Cara Belajar Yang Efisien. Yogyakarta: Gajah Mada University Press.

Mursiah, NK. 1985. Ketrampilan Guru Di Dalam Kelas. Bandung: Karunia.

Sawunggaling. 1984. Cara Belajar Siswa Aktif. Bandung: Sinar Baru.

Sukardi. 1993. Psikologi Pendidikan, Bandung: IKIP Bandung.

Walgito, Bimo. 2001. Bimbingan Dan Penyuluhan Di Sekolah, Yogjakarta: Andi Officer.

Yetero, Bakri. 1992. Efektifitas Belajar Kelompok Dalam Kelas Terhadap Prestasi Belajar Siswa. Palangkaraya: FKIP UNPAR. 